\title{
EFFECT OF NUTRIENT SOLUTION ON GROWTH AND YIELD OF CHERRY TOMATO VARIETIES IN SOILLESS CULTURE
}

\author{
Md. Shahajahan Ali ${ }^{1}$, Md. Jahedur Rahman ${ }^{2} \varangle$, Md. Nazrul Islam ${ }^{2}$, Md. Razzab Ali ${ }^{3}$, Md. Mofazzal \\ Hossain ${ }^{4}$, Md. Mokshed Ali ${ }^{5}$, Sujat Ahmed ${ }^{6}$ and Chand Sultana ${ }^{7}$ \\ ${ }^{1}$ PhD student, Department of Horticulture, Sher-e-Bangla Agricultural University, Dhaka, Bangladesh \\ ${ }^{2}$ Professor, Department of Horticulture, Sher-e-Bangla Agricultural University, Dhaka, Bangladesh \\ ${ }_{3}^{3}$ Professor, Department of Entomology, Sher-e-Bangla Agricultural University, Dhaka, Bangladesh \\ ${ }^{4}$ Professor, Department of Agriculture, City University, Dhaka, Bangladesh \\ 5 Program officer, Bangladesh Academy of Sciences, Dhaka, Bangladesh \\ ${ }^{6}$ MS student, Department of Agronomy, Sher-e-Bangla Agricultural University, Dhaka, Bangladesh \\ ${ }^{7}$ MS student, Department of Horticulture, Sher-e-Bangla Agricultural University, Dhaka, Bangladesh.
}

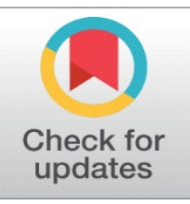

Received 16 September 2021

Accepted 16 October 2021

Published 31 October 2021

\section{CorrespondingAuthor}

Md. Jahedur Rahman, jrahman@sau.edu.bd

DOI

10.29121/granthaalayah.v9.i10.2021 .4244

Funding: This research was funded by Bangladesh Academy of Sciences and United State Department of Agriculture (BAS-USDA) under the project BAS USDA SAU CR-07.

Copyright: (C) 2021 The Author(s). This is an open access article distributed under the terms of the Creative Commons Attribution License, which permits unrestricted use, distribution, and reproduction in any medium, provided the original author and source are credited.

\section{ABSTRACT}

Nutrient solution and its nutritional compositions may have the effect on growth and fruit quality attributes of cherry tomato. To avoid the build-up of toxins, mineral deficiencies, nutrition abnormalities, or the spread of disease, producers should use optimum level of nutrient solution. Therefore, the present experiment was conducted to identify a suitable strength of nutrient solution for cherry tomato in hydroponic system. Treatment considered six levels of nutrient solution [viz., S1: 1/2 strength Rahman and Inden (2012), S2: 3/4 strength Rahman and Inden (2012), S3: Full strength Rahman and Inden (2012), S4: $1 / 2$ strength Arnon and Hoagland (1940), S5: 3/4 strength Arnon and Hoagland (1940) and S6: Full strength Arnon and Hoagland (1940) and two varieties [viz., V1: Local market cherry tomato (red), V2: Irelands cherry tomato (yellow)]. Growth and yield contributing characters, quality parameters, physiological traits and biochemical composition were analyzed. The maximum plant height, number of leaves per plant, first flowering, number of flowers per cluster, number of fruits per cluster, number of clusters per plant, average individual fruit weight and average cluster weight per plant were found in S3. Meanwhile, V2 performed better in respect of plant height, number of leaves per plant, first flowering, number of flowers per cluster, number of fruits per cluster, number of clusters per plant, average individual fruit weight and average cluster weight per plant. Therefore, cherry tomato cv. V2 can be cultured in hydroponic system with applying S3 (Full strength Rahman and Inden nutrient solution).

Keywords: Soilless Culture, Cherry Tomato, Yield, Nutrient Solution

\section{INTRODUCTION}

In recent years, agriculture of Bangladesh is under threats of climatic changes. Climatic change is detrimental in our agriculture sector. We need some alternatives technologies to relieve the effect of climate change on crops. Hydroponic technology has gained favor in recent years in the developing world because the population growth in all areas represented an opportunity to grow food near consumers Lakkireddy et al. (2012). In this system roots submerged in the nutrient solution Matos et al. (2015), with or without using dormant medium like rockwool and coconut fiber Mohanraj (2016), receives a balanced nutrition, essential for plant growth and development 
Hirofumi Ibayash et al. (2016). Again, hydroponics culture is becoming increasingly popular all over the world Avidan (2000). Hydroponic is suitable for coastal and hoar area areas in Bangladesh. Despite the considerable advantages of hydroponics, there are still some disadvantages, which restrict the further expansion of soilless cultivation in Bangladesh. In Bangladesh nutrient solution is one of the most important barriers for expansion of hydroponic crop culture. However, the concentration of nutrients can be controlled in the aqueous solution making it easier to observe the symptoms of nutrient deficiency or toxicity in plants Adrover et al. (2013), Resh (2012) and Da Silva Cuba et al. (2015). Many concentrated dry and liquid formulas are available in the market, but optimum dosage is very important to select for a specific crop.

Hydroponics has been used successfully to grow a variety of crops such as lettuce, cherry tomato, cucumber, herbs and many types of vegetables Asao (2012). Its advantages over conventional production systems are faster growth, higher productivity, easier handling, greater water efficiency Barbosa et al. (2015) and lesser use of fertilizers Rana et al. (2011) and Da Silva Cuba et al. (2015). Hydroponics crop make it possible to obtain good quality products, when compared to conventional systems. The advantages in this system include the high crop quality and yield, lower expenses with fertilizers and a more efficient use of water, besides a reduction in the environmental pollution and a greater control and efficient in the productive process Logendra (2009). It is protected from unfavorable weather conditions because it is generally stationed in controlled environment greenhouses, and has the added capability of year-round production Spray and Spray (2019). Lastly, it does not require the use of pesticides, because the risk of soil-borne diseases in plant is eliminated Viviano (2017).

The climatic condition of Bangladesh favors cherry tomato to grow in winter season and it can be cultivated in all parts of the country Haque et al. (1999). Now a day's several varieties of tomato have been developed for cultivation in summer season. Tomato (Solanum lycopersicum L.) belongs to the family solanaceae is one of the most popular and nutritious vegetables in Bangladesh Mondal et al. (2011). Due to its great acceptance in the market and compensating prices, tomato has been one of the most profitable vegetables for producers, being one of the most consumed and popular fruits of the world Nasir et al. (2015). Cherry tomato is grown for its edible fruits, which can be consumed either fresh as a salad or after cooking as snacks. They are perfect for making processed products like sauce, soup, ketchup, puree, curries, paste powder, rasam and sandwich. Unripe green fruits used for preparation of pickles and chutney. The fruit size ranges from thumb tip to the size of a golf ball. And can ranges from being spherical to slightly oblong in shape Anonymous (2009b). In addition to play an important role in the human diet, offering a diversified blend of nutrients Ilahy (2016), cherry tomato is rich in protein and carbohydrates Perveen (2015). However, the main highlight given to cherry tomato composition is the high levels of antioxidant compounds, such as phenolic compounds, vitamin C and carotenoids Vinha (2014). Lycopene is a very powerful antioxidant which can help prevent the development of many forms of cancer. Vitamin-C is important in forming collagen, a protein that gives structures to bones, cartilage, muscle and blood vessels. Excellent nutritional and processing qualities have made cherry tomato demand full in both domestic and foreign markets. Therefore, the present research was conducted to select an effective strength of nutrient solution and their effects growth, yield and quality of hydroponic cherry tomato, and to observe the performance of cherry tomato varieties in hydroponic system in Bangladesh. 


\section{MATERIALS AND METHODS}

Experimental site: The grow-bag experiment was conducted in the semigreenhouse at the Horticulture Farm of Sher-e-Bangla Agricultural University, Dhaka - 1207. The location of the study site is situated in $23^{\circ} 74 / \mathrm{N}$ latitude and $90^{\circ}$ $35 /$ E longitude. The altitude of the location was $8 \mathrm{~m}$ from the sea level (The Meteorological Department of Bangladesh, Agargaon, Dhaka). The grow-bag and pot experiments were conducted during October 2020 to May 2021.

Plant and other materials: In this research work, the seeds of cherry tomato (Solanum lycopersicum var. cerasiforme), Ireland and local market were used. The seeds were collected from Siddik Bazar, Gulistan, Dhaka. The materials for grow-bag preparation, viz., tripal, rope, cocopeat, rice husk, broken brick (khoa), etc were used. The material for drip irrigation system was used.

Experimental Design and treatments: The experiment was conducted in a Randomized Complete Block Design (RCBD) with four replications. Two factors [viz., Factor - A: Nutrient solution denoted as S; S1: $1 / 2$ strength Rahman and Inden (2012), S2: 3/4 strength Rahman and Inden (2012), S3: Full strength Rahman and Inden (2012), S4: 1/2 strength Arnon and Hoagland (1940), S5: 3/4 strength Arnon and Hoagland (1940) and S6: Full strength Arnon and Hoagland (1940), Factor - B: Variety denoted as V; V1: Local market cherry tomato (red), V2: Irelands cherry tomato (yellow)]. Three plants were considered as an experimental unit.

Preparation of grow-bag and growing media: The grow-bags were prepared with teerpal and rope. The length, breadth and height of a growbag were $100 \mathrm{~cm} \times$ $30 \mathrm{~cm} \times 20 \mathrm{~cm}$. The growbag was filled with the media mixture of coco peat, rich husk and broken brick (small khoa) at the ratio of 60: 30: $10(\mathrm{v} / \mathrm{v})$. Coco peat blocks were soaked in a plastic container for 24 hours. The soaked coco peat was washed well in water and spread in a polythene sheet for three hours. Rice husk and khoa were also washed with clean water and dry them. Then three ingredients such as coco peat, rice husk and khoa were mixed according to the ratio. After that the mixture was sterilized with $4 \%$ formaldehyde and covered for four days and after that they were mixed again and spread on the floor for three days. These mixtures put into the growbag.

Experimental environment: Twelve growbags with growing substrate mixture were prepared for culturing the plants. Growbags were placed on the surface of the semi greenhouse. Seedlings were raised in the cell trays and transferred into four-inch pot with the same growing substrates. Two-week-old seedlings were transferred into the four-inch pots. The room was kept clean and tidy during the time of the experiment. Daily supervision was maintained to protect plants. The $\mathrm{pH}$ and $\mathrm{EC}$ of the nutrient solutions were observed twice a week. The plants were irrigated with automated drip irrigation system. Temperature and relative humidity were recorded daily during the experimental period.

Seed sowing, rising and seedling transplanting: The seeds were soaked in water for 24 hours and then wrapped with piece of thin cloth. The socked seed were then spread over polythene sheet for 2 hours to dry out the surface water. After those seeds were sown into the cell trays and covered with newspaper under room temperature for rising seedling. Two-week old seedlings were transferred into the pots and took care of seedlings until transferred to the main hydroponic culture beds. Five-week-old seedlings were transferred into the growbags with $40-\mathrm{cm}$ distance. Seedlings were transferred in the afternoon and watering was done for a week. After those treatments were applied regularly. 
Data collection: Data on the growth, yield contributing characters, physiological traits and biochemical analysis were done during the experiment. Plant height $(\mathrm{cm})$ and number of leaves per plant were measured at 15, 30, 45, 60, 75 and 90 DAT (days after transplanting), days of first flower initiation, days of first fruit initiation, number of flowers per cluster, number of fruits per cluster, number of clusters per cluster, number of fruits per plant, individual fruit weight (g), average weight per cluster weight (g), average fruit weight per plant $(\mathrm{g})$ were recorded.

Statistical analysis: The data recorded on different were statistically analyzed to find out the statistical significance for the experimental results with SPSS version 26. The means for all the treatments were calculated and analyses of variance for all the characters were performed by Tukey's test at 0.05 level of significance.

\section{RESULTS AND DISCUSSION}

Plant height: Different strengths of nutrient solution had statistically significance effect on plant heights of cherry tomato at 15, 30, 45, 60, 75 and 90 DAT (days after transplanting) (Table 1). At 15 DAT, full strength Rahman and Inden solution (S3) produced the tallest plant $(23.94 \mathrm{~cm})$ and the shortest plant $(15.00$ $\mathrm{cm}$ ) was produced by $1 / 2$ strength Rahman and Inden solution (S1). At 30 DAT, full strength Rahman and Inden solution (S3) produced the tallest plant $(50.38 \mathrm{~cm})$ and the shortest plant $(28.35 \mathrm{~cm})$ was obtained from S4 treatment. Similarly, the tallest plants at 45, 60, 75 and 90 DAT $(66.75 \mathrm{~cm}, 108.50 \mathrm{~cm}, 120.75 \mathrm{~cm}$ and $124.50 \mathrm{~cm}$, respectively) were found in full strength of Rahman and Inden solution (S3) and the shortest plants at 45, 60, 75 and 90 DAT $(42.00 \mathrm{~cm}, 65.50 \mathrm{~cm}, 78.00 \mathrm{~cm}$ and 83.00 $\mathrm{cm}$, respectively) were found in S4. The results revealed that the plant heights of tomato increased with the increased in the strengths of nutrient solutions. This might be due that full strength Rhaman and Inden solution has ability to supply proper amount of nutrients required for the cherry tomato culture in hydroponic system. The results of the present study consistent with the results of Andriolo et al. (2005). They stated that lettuce growth was affected by different strength of nutrient solutions.

\begin{tabular}{|c|c|c|c|c|c|c|}
\hline \multirow[t]{2}{*}{ Treatments } & \multicolumn{6}{|c|}{ Plant heights (cm) } \\
\hline & 15 DAT & 30 DAT & 45 DAT & 60 DAT & 75 DAT & 90 DAT \\
\hline \multicolumn{7}{|c|}{ Nutrient Solution (S) } \\
\hline $\mathrm{S}_{1}$ & $15.00 \mathrm{~b}^{\mathrm{z}}$ & $32.75 \mathrm{~b}$ & $52.50 \mathrm{bc}$ & $77.00 \mathrm{dc}$ & $89.00 \mathrm{~cd}$ & $94.50 \mathrm{~cd}$ \\
\hline $\mathrm{S}_{2}$ & $18.56 \mathrm{ab}$ & $36.31 \mathrm{~b}$ & $56.63 \mathrm{~b}$ & $83.63 \mathrm{c}$ & $95.38 \mathrm{c}$ & $100.62 \mathrm{c}$ \\
\hline $\mathrm{S}_{3}$ & $23.94 \mathrm{a}$ & $50.38 \mathrm{a}$ & $66.75 \mathrm{a}$ & $108.50 \mathrm{a}$ & $120.75 \mathrm{a}$ & $124.50 \mathrm{a}$ \\
\hline $\mathrm{S}_{4}$ & $16.25 \mathrm{ab}$ & $28.35 \mathrm{~b}$ & $42.00 \mathrm{~d}$ & $65.50 \mathrm{e}$ & $78.00 \mathrm{e}$ & $83.00 \mathrm{e}$ \\
\hline $\mathrm{S}_{5}$ & $19.20 \mathrm{ab}$ & $32.00 \mathrm{~b}$ & $45.63 \mathrm{~cd}$ & $73.13 \mathrm{~d}$ & $85.13 \mathrm{~d}$ & $92.63 \mathrm{~d}$ \\
\hline $\mathrm{S}_{6}$ & $21.55 \mathrm{ab}$ & $37.60 \mathrm{~b}$ & $54.25 \mathrm{bc}$ & $93.25 \mathrm{~b}$ & $105.50 \mathrm{~b}$ & 110.5. b \\
\hline \multicolumn{7}{|l|}{ Variety (V) } \\
\hline$V_{1}$ & 22.47 & 39.11 & 55.58 & 80.50 & 92.75 & 95.50 \\
\hline $\mathrm{V}_{2}$ & 15.70 & 33.35 & 50.33 & 86.50 & 98.50 & 105.40 \\
\hline \multicolumn{7}{|c|}{ Level of significance $(P)$} \\
\hline S & 0.021 & 0.002 & $<0.001$ & $<0.001$ & $<0.001$ & $<0.001$ \\
\hline V & 0.001 & 0.011 & 0.159 & 0.347 & 0.031 & 0.042 \\
\hline
\end{tabular}


zMeans with different letter ( $\mathrm{s}$ ) is significantly different by Tukey's test at $\mathrm{P} \leq 0.05$. P represents the level of significance of two-way ANOVA. DAT - Days after transplanting. S1: $1 / 2$ strength Rahman and Inden (2012), S2: 3/4 strength Rahman and Inden (2012), S3: Full strength Rahman and Inden (2012), S4: $1 / 2$ strength Hoagland and Arnon No. 2(1940), S5: 3/4 strength Hoagland and Arnon No. 2(1940) and S6: Full strength Hoagland and Arnon No. 2 (1940). V1: Local market cherry tomato (red), V2: Irelands cherry tomato (yellow).

Varietal performance of cherry tomato had slightly differed in respect of plant height in soilless culture (Table 1). Plant heights at 15, 30, 75 and 90 DAT were differed significantly between two varieties. The tallest plants at 15, 30, 75 and 90 DAT (22.47 cm, $39.11 \mathrm{~cm}, 92.75 \mathrm{~cm}$ and $95.50 \mathrm{~cm}$, respectively) were produced from V1 variety and the shortest plants at 15, 30, 75 and 90 DAT $(15.70 \mathrm{~cm}, 33.35$ $\mathrm{cm}, 98.50 \mathrm{~cm}$ and $105.40 \mathrm{~cm}$, respectively) produced from V2. On the other hand, plant heights at 45 and 60 DAT had no significance difference between two varieties. The tallest plants at 45 and 60 DAT ( $55.58 \mathrm{~cm}$ and $87.50 \mathrm{~cm}$, respectively) were produced from V1 variety and the shortest plants at 45 and 60 DAT $(50.33 \mathrm{~cm}$ and $86.50 \mathrm{~cm}$, respectively) produce from V2. Plant height is one of the most important parameters, which is positively correlated with the yield of cherry tomato Asri et al. (2015). Islam et al. (2012) stated that the plant height of cherry tomato lines depends on genetically character. Kumar (2011) experimented on 74 Lines of tomatoes in Vanarashi, India and observed that the plant height was varied by different tomato varieties. The varietal performance of two cherry tomato in the present study consistent with the previous studies described above.

The combination of different strengths of nutrient solutions and varieties had the significant effects on plant heights at 15, 30, 45, 60, 75 and 90 DAT (Table 2). The tallest plants at 15, 30, 45, 60, 75 and 90 DAT $(29.62 \mathrm{~cm}, 59.25 \mathrm{~cm}, 69.25 \mathrm{~cm}$, $109.25 \mathrm{~cm}, 121.75 \mathrm{~cm}$ and $126.25 \mathrm{~cm}$, respectively) were found in S3V1. Meanwhile, the shortest plants at 15 and 30 DAT $(10.12 \mathrm{~cm}$ and $30.50 \mathrm{~cm})$ were found in S1V2. At 45 DAT, the shortest plant height $(39.50 \mathrm{~cm})$ was found in S4V2. On the other hands, the shortest plants at 60,75 and 90 DAT $(59.00 \mathrm{~cm}, 72.00 \mathrm{~cm}$ and $77.00 \mathrm{~cm}$, respectively) were found in S4V2. The variations among the treatment combinations might be due to the characteristics of varieties and variation of strengths of nutrient solutions applied.

\begin{tabular}{|c|c|c|c|c|c|c|}
\hline \multirow{2}{*}{$\begin{array}{l}\text { Treatment } \\
\text { combination }\end{array}$} & \multicolumn{6}{|c|}{ Plant heights $(\mathrm{cm})$} \\
\hline & 15 DAT & 30 DAT & 45 DAT & 60 DAT & 75 DAT & 90 DAT \\
\hline $\mathrm{S}_{1} \mathrm{~V} 1$ & $\begin{array}{c}19.87 \\
\mathrm{abc}^{\mathrm{z}}\end{array}$ & $35.00 \mathrm{~b}$ & 54.5 abcde & $70.00 \mathrm{efg}$ & $82.00 \mathrm{efg}$ & $87.00 \mathrm{gh}$ \\
\hline $\mathrm{S}_{1} \mathrm{~V}_{2}$ & $10.12 \mathrm{c}$ & $30.50 \mathrm{~b}$ & 50.50 bcde & $\begin{array}{c}84.00 \\
\text { bcd }\end{array}$ & $96.00 \mathrm{dc}$ & $102.00 \mathrm{cdef}$ \\
\hline $\mathrm{S}_{2} \mathrm{~V}_{1}$ & $23.50 \mathrm{abc}$ & $34.50 \mathrm{~b}$ & $59.50 \mathrm{abc}$ & $80.75 \mathrm{cde}$ & 92.75de & $97.75 \mathrm{defg}$ \\
\hline $\mathrm{S}_{2} \mathrm{~V}_{2}$ & $13.62 \mathrm{~b}$ & $38.12 b$ & $\begin{array}{l}53.75 \\
\text { abcde }\end{array}$ & $\begin{array}{c}86.50 \\
\text { bcd }\end{array}$ & $98.00 \mathrm{bcd}$ & $103.50 \mathrm{cde}$ \\
\hline $\mathrm{S}_{3} \mathrm{~V}_{1}$ & $29.62 \mathrm{a}$ & $59.25 \mathrm{a}$ & $69.25 \mathrm{a}$ & $109.25 \mathrm{a}$ & $121.75 \mathrm{a}$ & $126.25 \mathrm{a}$ \\
\hline $\mathrm{S}_{3} \mathrm{~V}_{2}$ & $18.25 \mathrm{abc}$ & $41.50 \mathrm{ab}$ & $64.25 \mathrm{ab}$ & $107.75 \mathrm{a}$ & $119.75 \mathrm{a}$ & $122.75 \mathrm{ab}$ \\
\hline $\mathrm{S}_{4} \mathrm{~V}_{1}$ & $17.00 \mathrm{abc}$ & $30.50 \mathrm{~b}$ & 44.50 cde & $72.00 \mathrm{ef}$ & $84.00 \mathrm{ef}$ & $89.00 \mathrm{~g}$ \\
\hline $\mathrm{S}_{4} \mathrm{~V}_{2}$ & $15.50 \mathrm{~b}$ & $26.20 \mathrm{~b}$ & $39.50 \mathrm{e}$ & $59.00 \mathrm{~g}$ & $72.00 \mathrm{~g}$ & $77.00 \mathrm{~h}$ \\
\hline
\end{tabular}




\begin{tabular}{ccccccc}
$\mathrm{S}_{5} \mathrm{~V}_{1}$ & $20.90 \mathrm{abc}$ & $32.50 \mathrm{~b}$ & $48.50 \mathrm{bcde}$ & $68.75 \mathrm{fg}$ & $80.75 \mathrm{fg}$ & $90.75 \mathrm{fg}$ \\
$\mathrm{S}_{5} \mathrm{~V}_{2}$ & $17.50 \mathrm{abc}$ & $31.50 \mathrm{~b}$ & $42.75 \mathrm{de}$ & $77.50 \mathrm{def}$ & $89.50 \mathrm{def}$ & $94.50 \mathrm{efg}$ \\
\hline $\mathrm{S}_{6} \mathrm{~V}_{1}$ & $23.90 \mathrm{ab}$ & $39.30 \mathrm{ab}$ & $57.25 \mathrm{abcd}$ & $95.25 \mathrm{~b}$ & $107.25 \mathrm{~b}$ & $112.25 \mathrm{bc}$ \\
$\mathrm{S}_{6} \mathrm{~V}_{2}$ & $19.20 \mathrm{abc}$ & $35.90 \mathrm{~b}$ & $51.25 \mathrm{bcde}$ & $91.25 \mathrm{bc}$ & $103.75 \mathrm{bc}$ & $108.75 \mathrm{~cd}$ \\
$\begin{array}{c}\text { Level of significance } \\
(\boldsymbol{P})\end{array}$ & 0.009 & 0.003 & $<0.001$ & $<0.001$ & $<0.001$ & $<0.001$ \\
\hline
\end{tabular}

zMeans with different letter (s) is significantly different by Tukey's test at $\mathrm{P} \leq 0.05$. P represents the level of significance of two-way ANOVA. DAT - Days after transplanting. S1: $1 / 2$ strength Rahman and Inden (2012), S2: 3/4 strength Rahman and Inden (2012), S3: Full strength Rahman and Inden (2012), S4: 1/2 strength Hoagland and Arnon No. 2(1940), S5: 3/4 strength Hoagland and Arnon No. 2(1940) and S6: Full strength Hoagland and Arnon No. 2 (1940). V1: Local market cherry tomato (red), V2: Irelands cherry tomato (yellow).

Number of leaves per plant: The effect of different strength of nutrient solutions on number of leaves per at $15,30,45,60,75$ and 90 DAT were significance differences among the treatments (Table 3). Full strength Rhaman and Inden (S3) solution produced the maximum number of leaves per plant at 15, 30, 45, 60, 75 and 90 DAT $(8.30,13.30,20.30,25.30,31.30$ and 34.30 number of leaves per plant, respectively). Meanwhile, S4 solution produced the minimum number of leaves per plant at 15, 30, 45, 60, 75 and 90 DAT (4.82, 7.88, 12.87, 15.88, 20.88 and 22.87 number of leaves per plant, respectively). Results revealed that the production of leaves per plants increased with the increased in the strength of nutrient solution. Full strength Rhaman and Inden solution performed better and it might be due to the ability of supply all the nutrients in right amounts to the cherry tomato. A study conducted by Logendra (2009) reported that an increased in the number of leaves elevated the photosynthetic reaction and increased carbohydrates by using all essential nutrient elements and proper strength. The present results consisted with the finding of Logendra (2009).

Table 3 Main effects of nutrient solutions and varieties on number of leaf per plant at different days after transplanting of cherry tomato

\begin{tabular}{|c|c|c|c|c|c|c|c|}
\hline \multirow[t]{2}{*}{ Treatments } & \multicolumn{7}{|c|}{ Number of leaf per plant } \\
\hline & $\begin{array}{c}30 \\
\text { DAT }\end{array}$ & $\begin{array}{c}45 \\
\text { DAT }\end{array}$ & 60 DAT & & & 90 DAT & \\
\hline \multicolumn{8}{|l|}{ Nutrient Solution (S) } \\
\hline $\mathrm{S}_{1}$ & & $5.88 c^{z}$ & $10.88 c$ & $17.87 \mathrm{c}$ & $22.87 \mathrm{c}$ & $28.88 \mathrm{c}$ & $31.88 c$ \\
\hline $\mathrm{S}_{2}$ & & $7.35 \mathrm{~b}$ & $12.35 \mathrm{~b}$ & $19.35 \mathrm{~b}$ & $24.35 \mathrm{~b}$ & $30.35 \mathrm{~b}$ & $33.35 \mathrm{~b}$ \\
\hline $\mathrm{S}_{3}$ & & $8.30 \mathrm{a}$ & $13.30 \mathrm{a}$ & $20.30 a$ & $25.30 \mathrm{a}$ & $31.30 \mathrm{a}$ & $34.30 \mathrm{a}$ \\
\hline $\mathrm{S}_{4}$ & & $4.82 \mathrm{~d}$ & $7.88 \mathrm{e}$ & $12.87 \mathrm{f}$ & $15.88 \mathrm{f}$ & $20.88 \mathrm{f}$ & $22.87 \mathrm{f}$ \\
\hline $\mathrm{S}_{5}$ & & $6.15 \mathrm{c}$ & $9.15 \mathrm{~d}$ & $13.90 \mathrm{e}$ & $16.90 \mathrm{e}$ & $21.90 \mathrm{e}$ & $23.90 \mathrm{e}$ \\
\hline $\mathrm{S}_{6}$ & & $7.45 \mathrm{ab}$ & $10.45 \mathrm{c}$ & $\begin{array}{c}15.45 \\
d\end{array}$ & $18.45 \mathrm{~d}$ & $23.45 \mathrm{~d}$ & $25.45 \mathrm{~d}$ \\
\hline \multicolumn{8}{|l|}{ Variety (V) } \\
\hline $\mathrm{V}_{1}$ & & 6.22 & 10.22 & 16.13 & 20.13 & 25.63 & 28.13 \\
\hline $\mathrm{V}_{2}$ & & 7.12 & 11.12 & 17.12 & 21.12 & 26.62 & 29.12 \\
\hline \multicolumn{8}{|c|}{ Level of significance $(P)$} \\
\hline $\mathrm{S}$ & & 0.000 & 0.000 & 0.000 & 0.000 & 0.000 & 0.325 \\
\hline $\mathrm{V}$ & & 0.269 & 0.416 & 0.542 & 0.588 & 0.627 & 0.169 \\
\hline
\end{tabular}


zMeans with different letter ( $\mathrm{s}$ ) is significantly different by Tukey's test at $\mathrm{P} \leq 0.05$. P represents the level of significance of two-way ANOVA. DAT - Days after transplanting. S1: $1 / 2$ strength Rahman and Inden (2012), S2: 3/4 strength Rahman and Inden (2012), S3: Full strength Rahman and Inden (2012), S4: $1 / 2$ strength Hoagland and Arnon No. 2(1940), S5: 3/4 strength Hoagland and Arnon No. 2(1940) and S6: Full strength Hoagland and Arnon No. 2 (1940). V1: Local market cherry tomato (red), V2: Irelands cherry tomato (yellow).

The number of leaves is the significant character for plant development and advancement, as leaf is the fundamental photosynthetic organ which has direct connection to yield of the plant. An insignificant variation was found between the varieties of cherry tomato in respect of the number of leaves per plant at 15, 30, 45, 60, 75 and 90 DAT (Table 3). Number of leaves per plant was recorded at 15 and 30 DAT (days after transplanting). The maximum number of leaves per plant was found in V2 at 15, 30, 45, 60, 75 and 90 DAT $(6.22,10.22,16.13,20.13,25.63$ and 28.13 number of leaf per plant, respectively). Whereas the minimum number of leaves was found in V1 at 15, 30, 45, 60, 75 and 90 DAT (7.12, 11.12, 17.12, 21.12, 26.62 and 29.12 Number of leaf per plant, respectively). The size of the leaf and number of leaves per plant decides the efficiency of photosynthesis activity which contributed towards better growth and yield the results were in confirmation with Deepa and Thakur (2008) and Arun et al. (2004). Similar results were reported by Sharma and Tiwari (2015). But the present study revealed that both the varieties of cherry tomato performed similar in respect of number of leaves per plant. This might be due to the varietal characteristics also.

The combination of different strength of nutrient solutions and varieties had significant effects on number of leaves per plant of cherry tomato at at 15, 30, 45, 60, 75 and 90 DAT (Table 4). At 15, 30, 45, 60, 75 and 90 DAT $(8.85,13.85,20.85$, $25.85,31.85$ and 34.85 number of leaves per plant, respectively), S3V2 treatment combination produced the maximum number of leaves per plant. On the other hands, the minimum number of leaves was found in V1 at 15, 30, 45, 60, 75 and 90 DAT $(4.75,7.75,12.75,15.75,20.75$ and 22.75 number of leaf per plant, respectively). The variations among the treatment combinations were the characteristics of different varieties and variation of different strength of nutrient solutions.

Table 4 Interaction effects of nutrient solutions and varieties on number of leaf per plant at different days after transplanting of cherry tomato.

\begin{tabular}{ccccccc}
\hline Treatment combination & \multicolumn{7}{c}{ Number of leaf per plant } \\
& $\mathbf{1 5}$ DAT & 30 DAT & 45 DAT & 60 DAT & $\mathbf{7 5 ~ D A T}$ & $\mathbf{9 0 ~ D A T}$ \\
\hline $\mathrm{S}_{1} \mathrm{~V}_{1}$ & $5.75 \mathrm{def}^{z}$ & $10.75 \mathrm{dc}$ & $17.75 \mathrm{c}$ & $22.75 \mathrm{c}$ & $28.75 \mathrm{c}$ & $31.75 \mathrm{c}$ \\
$\mathrm{S}_{1} \mathrm{~V}_{2}$ & $6.00 \mathrm{def}$ & $11.00 \mathrm{dc}$ & $18.00 \mathrm{c}$ & $23.00 \mathrm{c}$ & $29.01 \mathrm{c}$ & $32.00 \mathrm{c}$ \\
$\mathrm{S}_{2} \mathrm{~V}_{1}$ & $6.50 \mathrm{cde}$ & $11.5 \mathrm{abc}$ & $18.50 \mathrm{bc}$ & $23.50 \mathrm{bc}$ & $29.51 \mathrm{bc}$ & $32.50 \mathrm{bc}$ \\
\hline $\mathrm{S}_{2} \mathrm{~V}_{2}$ & $8.20 \mathrm{ab}$ & $13.20 \mathrm{a}$ & $20.20 \mathrm{a}$ & $25.20 \mathrm{a}$ & $31.21 \mathrm{a}$ & $34.20 \mathrm{a}$ \\
\hline $\mathrm{S}_{3} \mathrm{~V}_{1}$ & $7.75 \mathrm{abc}$ & $12.75 \mathrm{ab}$ & $19.75 \mathrm{ab}$ & $24.75 \mathrm{ab}$ & $30.75 \mathrm{ab}$ & $33.75 \mathrm{ab}$ \\
$\mathrm{S}_{3} \mathrm{~V}_{2}$ & $8.85 \mathrm{a}$ & $13.85 \mathrm{a}$ & $20.85 \mathrm{a}$ & $25.85 \mathrm{a}$ & $31.85 \mathrm{a}$ & $34.85 \mathrm{a}$ \\
$\mathrm{S}_{4} \mathrm{~V}_{1}$ & $4.75 \mathrm{f}$ & $7.75 \mathrm{f}$ & $12.75 \mathrm{e}$ & $15.75 \mathrm{e}$ & $20.75 \mathrm{e}$ & $22.75 \mathrm{e}$ \\
$\mathrm{S}_{4} \mathrm{~V}_{2}$ & $5.00 \mathrm{f}$ & $8.00 \mathrm{f}$ & $13.00 \mathrm{e}$ & $16.00 \mathrm{e}$ & $21.01 \mathrm{e}$ & $23.08 \mathrm{e}$ \\
$\mathrm{S}_{5} \mathrm{~V}_{1}$ & $5.50 \mathrm{ef}$ & $8.50 \mathrm{ef}$ & $13.00 \mathrm{e}$ & $16.00 \mathrm{e}$ & $21.00 \mathrm{e}$ & $23.02 \mathrm{e}$ \\
$\mathrm{S}_{5} \mathrm{~V}_{2}$ & $6.80 \mathrm{bcde}$ & $9.80 \mathrm{de}$ & $14.80 \mathrm{~d}$ & $17.80 \mathrm{~d}$ & $22.80 \mathrm{~d}$ & $24.80 \mathrm{~d}$ \\
\hline
\end{tabular}




\begin{tabular}{ccccccc}
$\mathrm{S}_{6} \mathrm{~V}_{1}$ & $7.05 \mathrm{bcd}$ & $10.05 \mathrm{~d}$ & $15.05 \mathrm{~d}$ & $18.05 \mathrm{~d}$ & $23.05 \mathrm{~d}$ & $25.05 \mathrm{~d}$ \\
$\mathrm{~S}_{6} \mathrm{~V}_{2}$ & $7.85 \mathrm{abc}$ & $10.85 \mathrm{dc}$ & $15.85 \mathrm{~d}$ & $18.85 \mathrm{~d}$ & $23.85 \mathrm{~d}$ & $25.85 \mathrm{~d}$ \\
$\begin{array}{c}\text { Level of significance } \\
(\boldsymbol{P})\end{array}$ & $<0.001$ & $<0.001$ & $<0.001$ & $<0.001$ & $<0.001$ & $<0.001$ \\
\hline
\end{tabular}

zMeans with different letter ( $\mathrm{s}$ ) is significantly different by Tukey's test at $\mathrm{P} \leq 0.05$. P represents the level of significance of two-way ANOVA. DAT - Days after transplanting. S1: $1 / 2$ strength Rahman and Inden (2012), S2: 3/4 strength Rahman and Inden (2012), S3: Full strength Rahman and Inden (2012), S4: 1/2 strength Hoagland and Arnon No. 2(1940), S5: 3/4 strength Hoagland and Arnon No. 2(1940) and S6: Full strength Hoagland and Arnon No. 2 (1940). V1: Local market cherry tomato (red), V2: Irelands cherry tomato (yellow).

First flowering of plant: The different strengths of nutrient solutions had shown insignificant effect on the first flowering of cherry tomato. The minimum days required for first flowering was observed in the plants when applied S3 (18.50 DAT). The maximum days required for the first flowering was observed in S4 (21.88 DAT). Results revealed that first flowering was differed with the increased in nutrient solution. However, full strength Rahman and Inden solution produced the first flower in the shortest days after transplanting of cherry tomato. This might be because of balanced nutrients supplied by the full strength of Rahman and Inden solution which consequent increment in photosynthesis. On the contrary, other strengths of nutrient solutions were supply lower amount of nutrient and probably the result of such phenomenon reduce photosynthesis of the plants.

First flowering of cherry tomato was observed insignificantly effect on varieties (Table 5). The minimum days required for first flowering was observed in V1 (19.50 DAT) and the maximum was found in V2 (20.75 DAT). Early flowering is an indication of early fruit formation and consequently helps in getting early and high yields. The early flower initiation in V1 might be due to higher capacity of these growing types to make available assimilates to the reproductive site during sensitive phase before flower initiation and congenial micro climate inside the semigreenhouse. Similar results reported by Thangam and Thamburaj (2008) in tomato and Prema et al. (2011) in cherry tomato.

\begin{tabular}{|c|c|c|c|c|c|}
\hline $\begin{array}{c}\text { Treatment } \\
\text { s }\end{array}$ & $\begin{array}{c}\text { First Flowering } \\
\text { at DAT }\end{array}$ & $\begin{array}{l}\text { First Fruiting } \\
\text { at DAT }\end{array}$ & $\begin{array}{l}\text { Flower per } \\
\text { cluster }\end{array}$ & $\begin{array}{l}\text { Fruit per } \\
\text { cluster }\end{array}$ & $\begin{array}{c}\text { Cluster per } \\
\text { plant }\end{array}$ \\
\hline \multicolumn{6}{|c|}{ Nutrient Solution (S) } \\
\hline $\mathrm{S}_{1}$ & 20.88 & 32.38 & $8.62 \mathrm{~d}^{\mathrm{z}}$ & $7.12 \mathrm{e}$ & $9.38 \mathrm{~d}$ \\
\hline $\mathrm{S}_{2}$ & 19.50 & 29.88 & $11.56 \mathrm{c}$ & $10.06 \mathrm{c}$ & $11.81 \mathrm{bc}$ \\
\hline $\mathrm{S}_{3}$ & 18.50 & 27.75 & $16.81 \mathrm{a}$ & $13.31 \mathrm{a}$ & $15.88 \mathrm{a}$ \\
\hline $\mathrm{S}_{4}$ & 21.88 & 33.38 & $8.00 \mathrm{~d}$ & $7.00 \mathrm{e}$ & 8.10 e \\
\hline $\mathrm{S}_{5}$ & 20.50 & 30.88 & $11.06 \mathrm{c}$ & $8.81 \mathrm{~d}$ & $11.00 \mathrm{c}$ \\
\hline $\mathrm{S}_{6}$ & 19.50 & 28.75 & $13.75 \mathrm{~b}$ & $11.25 \mathrm{~b}$ & $12.60 \mathrm{~b}$ \\
\hline \multicolumn{6}{|c|}{ Variety (V) } \\
\hline $\mathrm{V}_{1}$ & 19.50 & 31.42 & 10.77 & 8.85 & 10.70 \\
\hline $\mathrm{V}_{2}$ & 20.75 & 29.58 & 12.50 & 10.33 & 12.23 \\
\hline \multicolumn{6}{|c|}{ Level of significance $(P)$} \\
\hline S & 0.059 & 0.062 & $<0.001$ & $<0.001$ & $<0.001$ \\
\hline V & 0.141 & 0.196 & 0.142 & 0.166 & 0.079 \\
\hline
\end{tabular}


zMeans with different letter ( $\mathrm{s}$ ) is significantly different by Tukey's test at $\mathrm{P} \leq 0.05$. P represents the level of significance of two-way ANOVA. DAT - Days after transplanting S1: $1 / 2$ strength Rahman and Inden (2012), S2: 3/4 strength Rahman and Inden (2012), S3: Full strength Rahman and Inden (2012), S4: $1 / 2$ strength Hoagland and Arnon No. 2(1940), S5: 3/4 strength Hoagland and Arnon No. 2(1940) and S6: Full strength Hoagland and Arnon No. 2 (1940). V1: Local market cherry tomato (red), V2: Irelands cherry tomato (yellow).

Insignificant variation was noted on the first flowering influenced by combined effect of different strength of nutrient solutions and varieties (Table 6). The minimum days required for first flowering was recorded from the treatment combination S3V1 (18.00 DAT) and the minimum days was found in S4V2 (22.75 DAT).

First Fruiting: The different strengths of the nutrient solution did not show significant effect on first fruiting of cherry tomato (Table 5). The minimum days required for first fruiting was observed in the plants when applied S3 (27.75 DAT). The maximum days required for the first flowering was observed in S4 (33.38 DAT). Results revealed that first flowering was differed with the increased in nutrient solution. However, full strength Rahman and Inden solution produced the first flower in the shortest days after transplanting of cherry tomato. This was because full strength Rahman and Inden solution can have ability to maintain nutrient element in root zone enhances the protein synthesis, cell division, cell elongation and thereby stimulated fruiting.

First fruiting of cherry tomato did not significantly affected by different varieties (Table 5). The V2 required the shortest days (29.58 DAT) for first fruiting and V1 required the maximum days (31.42 DAT) for first fruiting of cherry tomato. Earliness plays important role on fetching higher price and more income. Therefore, early varieties are generally preferred for cultivation on commercial scale. Early harvest in this experiment might be due to the varietal response to the congenial growing environment in semi-greenhouse and early flowering. Whereas delayed fruit ripening was due to late flowering. Similar results obtained by Prema et al. (2011) in cherry tomato.

Insignificant variation was found on first fruiting influenced by combined effect of different strength of nutrient solutions and tomato varieties (Table 6). The minimum days required for first fruiting was recorded from S3V2 (27.00 DAT) and the maximum days required for first fruiting was found in S4V1 (34.75 DAT).

\begin{tabular}{cccccc}
\hline \multicolumn{5}{c}{$\begin{array}{c}\text { Table } 6 \text { Interaction effects of nutrient solutions and varieties on first flowering, first } \\
\text { fruiting, flower per cluster, fruit per cluster and cluster per plant of cherry tomato. }\end{array}$} \\
\hline $\begin{array}{c}\text { Treatment } \\
\text { combinations }\end{array}$ & $\begin{array}{c}\text { First } \\
\text { Flowering at } \\
\text { DAT }\end{array}$ & $\begin{array}{c}\text { First } \\
\text { Fruiting at } \\
\text { DAT }\end{array}$ & $\begin{array}{c}\text { Flower per } \\
\text { cluster }\end{array}$ & $\begin{array}{c}\text { Fruit per } \\
\text { cluster }\end{array}$ & $\begin{array}{c}\text { Cluster per } \\
\text { plant }\end{array}$ \\
\hline $\mathrm{S}_{1} \mathrm{~V}_{1}$ & 20.00 & 33.75 & $8.25 \mathrm{gh}^{\mathrm{z}}$ & $6.63 \mathrm{ef}$ & $8.50 \mathrm{gh}$ \\
\hline $\mathrm{S}_{1} \mathrm{~V}_{2}$ & 21.75 & 31.00 & $9.00 \mathrm{gh}$ & $8.00 \mathrm{~d}$ & $10.25 \mathrm{efg}$ \\
$\mathrm{S}_{2} \mathrm{~V}_{1}$ & 19.00 & 30.50 & $10.75 \mathrm{ef}$ & $9.75 \mathrm{c}$ & $11.12 \mathrm{de}$ \\
\hline $\mathrm{S}_{2} \mathrm{~V}_{2}$ & 20.00 & 29.25 & $12.38 \mathrm{de}$ & $10.38 \mathrm{c}$ & $12.50 \mathrm{~cd}$ \\
$\mathrm{~S}_{3} \mathrm{~V}_{1}$ & 18.00 & 28.50 & $15.50 \mathrm{~b}$ & $12.00 \mathrm{~b}$ & $14.75 \mathrm{~b}$ \\
$\mathrm{~S}_{3} \mathrm{~V}_{2}$ & 19.00 & 27.00 & $18.13 \mathrm{a}$ & $14.63 \mathrm{a}$ & $17.00 \mathrm{a}$ \\
$\mathrm{S}_{4} \mathrm{~V}_{1}$ & 21.00 & 34.75 & $7.63 \mathrm{~h}$ & $6.25 \mathrm{f}$ & $7.50 \mathrm{~h}$ \\
$\mathrm{~S}_{4} \mathrm{~V}_{2}$ & 22.75 & 32.00 & $8.38 \mathrm{gh}$ & $7.38 \mathrm{de}$ & $8.70 \mathrm{fgh}$ \\
\hline
\end{tabular}




\begin{tabular}{cccccc}
$\mathrm{S}_{5} \mathrm{~V}_{1}$ & 20.00 & 31.50 & $9.50 \mathrm{fg}$ & $8.00 \mathrm{~d}$ & $10.50 \mathrm{ef}$ \\
$\mathrm{S}_{5} \mathrm{~V}_{2}$ & 21.00 & 30.25 & $12.63 \mathrm{~d}$ & $9.63 \mathrm{c}$ & $11.50 \mathrm{de}$ \\
$\mathrm{S}_{6} \mathrm{~V}_{1}$ & 19.00 & 29.50 & $13.00 \mathrm{~cd}$ & $10.50 \mathrm{c}$ & $11.80 \mathrm{cde}$ \\
$\mathrm{S}_{6} \mathrm{~V}_{2}$ & 20.00 & 28.00 & $14.50 \mathrm{bc}$ & $12.00 \mathrm{~b}$ & $13.40 \mathrm{bc}$ \\
$\begin{array}{c}\text { Level of } \\
\text { significance }(\boldsymbol{P})\end{array}$ & 0.807 & 0.328 & $<0.001$ & $<0.001$ & $<0.001$ \\
\hline
\end{tabular}

zMeans with different letter ( $\mathrm{s}$ ) is significantly different by Tukey's test at $\mathrm{P} \leq 0.05$. P represents the level of significance of two-way ANOVA. DAT - Days after transplanting. S1: $1 / 2$ strength Rahman and Inden (2012), S2: 3/4 strength Rahman and Inden (2012), S3: Full strength Rahman and Inden (2012), S4: $1 / 2$ strength Hoagland and Arnon No. 2(1940), S5: 3/4 strength Hoagland and Arnon No. 2(1940) and S6: Full strength Hoagland and Arnon No. 2 (1940). V1: Local market cherry tomato (red), V2: Irelands cherry tomato (yellow).

Number of flowers per cluster: Significant variation was recorded in terms of number of flowers per cluster of cherry tomato due to different strengths of nutrient solutions treatment (Table 5). The highest number of flowers per cluster (18.81) was recorded from S3 treatment, whereas the lowest number of flowers per cluster (8.00) was found from S4 treatment. The result revealed that number of flowers per cluster increased with the increased in the strength of nutrient solutions. Treatment S3 produced the highest number of flowers that might be due to maintain optimum amount of macro and micro nutrients to allow grow faster, rate of metabolism, cell division, cell elongation. It also might maintain optimum EC level which increased in leaf water potential, leaf area and the consequent increment in photosynthesis that enhances the protein synthesis and thereby stimulated flower production. Garrison et al. (2010) reported that increasing levels of nitrogen increased flower formation of several clusters of processing cherry tomato.

Different varieties of cherry tomato varied significantly on number of flowers per cluster (Table 5). The highest number of flowers per cluster (12.50) was recorded from V2 and the lowest number of flowers per cluster (10.77) was recorded from $V 1$. This variation in number of flowers per cluster production among cherry tomato genotypes might be attributed to the inherent genetic potentiality of the genotypes to produce flowers at controlled environmental condition. Similar results were obtained by Parvej et al. (2010) in poly house tomato and Prema et al. (2011) in cherry tomato. Aguirre and Cabrera (2012) reported that number of inflorescences and stigma exertion are inherent characters.

Combined effect of different strength of nutrient solutions and varieties observed significant variation on number of flowers per cluster (Table 6). The highest number of flowers per cluster (18.13) was observed from S3V2, whereas the lowest number of flowers per cluster (7.63) was attained from S4V1.

Number of fruits per cluster: Significant variation was recorded in terms of number of fruits per cluster of cherry tomato due to different strengths of nutrient solutions treatment (Table 5). The highest number of fruits per cluster (13.31) was recorded from S3 treatment, whereas the lowest number of fruits per cluster (7.00) was found from S4 treatment. The result revealed that number of fruits per cluster increased with the increased in the strength of nutrient solutions. Treatment S3 produced the highest number of fruits that might be due to maintain optimum amount of macro and micro nutrients to allow grow faster, rate of metabolism, cell division, cell elongation. The results of the present research were consisted with the findings of Garrison et al. (2010).

Different varieties of cherry tomato varied significantly on number of fruits per cluster (Table 5). The highest number of fruits per cluster (10.33) was recorded 
from V2 and the lowest number of fruits per cluster (8.85) was recorded from V1. This variation in number of fruits per cluster production among cherry tomato genotypes might be attributed to the inherent genetic potentiality of the genotypes to produce flowers at controlled environmental condition. Similar results were obtained by Parvej et al. (2010) in poly house tomato.

Combined effect of different strength of nutrient solutions and varieties observed significant variation on number of fruits per cluster (Table 6). The highest number of fruits per cluster (14.63) was observed from S3V2, whereas the lowest number of fruits per cluster (6.25) was attained from S4V1.

Number of clusters per plant: Significant variation was recorded in terms of number of clusters per plant of cherry tomato due to different strengths of nutrient solutions treatment (Table 5). The highest number of clusters per plant (15.88) was recorded from S3 treatment, whereas the lowest number of clusters per plant (8.10) was found from S4 treatment. The result revealed that number of clusters per plant increased with the increased in the strength of nutrient solutions. Treatment S3 produced the highest number of clusters per plant that might be due to maintain optimum amount of macro and micro nutrients to allow grow faster, rate of metabolism, cell division, cell elongation. The results of the present research was consisted with the findings of Garrison et al. (2010).

Different varieties of cherry tomato varied significantly on number of clusters per plant (Table 5). The highest number of clusters per plant (12.23) was recorded from V2 and the lowest number of clusters per plant (10.70) was recorded from V1. This variation in number of clusters per plant production among cherry tomato genotypes might be attributed to the inherent genetic potentiality of the genotypes to produce flowers at controlled environmental condition. Similar results were obtained by Parvej et al. (2010) in poly house tomato.

Combined effect of different strength of nutrient solutions and varieties observed significant variation on number of clusters per plant (Table 6). The highest number of clusters per plant (17.00) was observed from S3V2, whereas the lowest number of clusters per plant (7.50) was attained from S4V1.

Individual fruit weight: Significant differences on individual fruit weight was observed among the strengths of nutrient solution (Table 7). The maximum individual fruit weight (33.75 g) was recorded from S3 and the minimum (17.75 g) was recorded from S1. This might be due to that full strength of Rhaman and Inden contained all plant nutrient elements in proper proportion which helped the plants developing a larger size and shape of fruits. The plants required optimum nutrient combination for proper growth and better yield stated by Quamruzzaman et al. (2017). The results of the present study were consisted with the findings of Nandapuri et al. (1973) and Ahmed et al. (1988).

Table 7 Main effects of nutrient solutions and varieties on individual fruit weight, average fruit per cluster and average fruit weight per plant of cherry tomato.

\begin{tabular}{cccc}
$\begin{array}{c}\text { Nutrient } \\
\text { Solution }\end{array}$ & $\begin{array}{c}\text { Individual fruit } \\
\text { weight (g) }\end{array}$ & $\begin{array}{c}\text { Average weight per } \\
\text { cluster (g) }\end{array}$ & $\begin{array}{c}\text { Average fruit weight per } \\
\text { plant (g) }\end{array}$ \\
\hline $\mathrm{S}_{1}$ & $19.25 \mathrm{de}^{\mathrm{z}}$ & $139.06 \mathrm{e}$ & $1333.20 \mathrm{e}$ \\
$\mathrm{S}_{2}$ & $23.38 \mathrm{c}$ & $236.33 \mathrm{c}$ & $2819.60 \mathrm{c}$ \\
$\mathrm{S}_{3}$ & $33.75 \mathrm{a}$ & $451.96 \mathrm{a}$ & $7250.10 \mathrm{a}$ \\
$\mathrm{S}_{4}$ & $17.75 \mathrm{e}$ & $125.13 \mathrm{e}$ & $1028.50 \mathrm{e}$ \\
\hline
\end{tabular}


Effect of Nutrient Solution on Growth and Yield of Cherry Tomato Varieties in Soilless Culture

$\begin{array}{cccc}\mathrm{S}_{5} & 21.13 \mathrm{~d} & 187.92 \mathrm{~d} & 2085.10 \mathrm{~d} \\ \mathrm{~S}_{6} & 29.25 \mathrm{~b} & 330.31 \mathrm{~b} & 4194.40 \mathrm{~b} \\ & & \text { Variety }(\mathbf{V}) & 2416.00 \\ \mathrm{~V}_{1} & 21.83 & 204.70 & 3821.00 \\ \mathrm{~V}_{2} & 26.33 & 285.50 & \\ & & \text { Level of significance }(\boldsymbol{P}) & 0.001 \\ \mathrm{~S} & 0.000 & 0.000 & 0.001 \\ \mathrm{~V} & 0.117 & 0.143 & \end{array}$

zMeans with different letter ( $\mathrm{s}$ ) is significantly different by Tukey's test at $\mathrm{P} \leq 0.05$. P represents the level of significance of two-way ANOVA. DAT - Days after transplanting. S1: $1 / 2$ strength Rahman and Inden (2012), S2: 3/4 strength Rahman and Inden (2012), S3: Full strength Rahman and Inden (2012), S4: 1/2 strength Hoagland and Arnon No. 2(1940), S5: 3/4 strength Hoagland and Arnon No. 2(1940) and S6: Full strength Hoagland and Arnon No. 2 (1940). V1: Local market cherry tomato (red), V2: Irelands cherry tomato (yellow).

Different varieties showed significant differences in respect of individual fruit weight of cherry tomato (Table 7). The highest individual fruit weight (26.33 g) was attained from V2, whereas the lowest (21.83 g) was recorded from V1. The fruit weight varied with fruit size and shape which are the varietal characters. The results of present investigation were in accordance with the finding of Prema et al. (2011) and Islam et al. (2012) in cherry tomato.

Significant difference on individual fruit weight was observed among the different strengths of nutrient solution and varieties (Table 8). The highest individual fruit weight (35.75 g) was recorded from S3V2 and the lowest (15.50 g) was observed from S4V1.

Table 8 Interaction effects of nutrient solutions and varieties on individual fruit weight, average fruit per cluster and average fruit weight per plant of cherry tomato.

\begin{tabular}{|c|c|c|c|}
\hline $\begin{array}{c}\text { Treatment } \\
\text { combinations }\end{array}$ & $\begin{array}{l}\text { Individual fruit } \\
\text { weight (g) }\end{array}$ & $\begin{array}{l}\text { Average weight per } \\
\text { cluster (g) }\end{array}$ & $\begin{array}{c}\text { Average fruit weight } \\
\text { per plant (g) }\end{array}$ \\
\hline $\mathrm{M}_{1} \mathrm{~V} 1$ & $17.00 \mathrm{gh}^{\mathrm{z}}$ & $106.12 \mathrm{f}$ & $901.50 \mathrm{gh}$ \\
\hline $\mathrm{S}_{1} \mathrm{~V}_{2}$ & 21.50 ef & $172.00 \mathrm{e}$ & $1765.00 \mathrm{ef}$ \\
\hline $\mathrm{S}_{2} \mathrm{~V}_{1}$ & $20.25 \mathrm{efg}$ & $195.00 \mathrm{e}$ & 2168.40 de \\
\hline $\mathrm{S}_{2} \mathrm{~V}_{2}$ & $26.75 \mathrm{~d}$ & $277.66 \mathrm{c}$ & $3470.70 \mathrm{c}$ \\
\hline $\mathrm{S}_{3} \mathrm{~V}_{1}$ & $31.75 \mathrm{~b}$ & $381.00 \mathrm{~b}$ & $5616.80 \mathrm{~b}$ \\
\hline $\mathrm{S}_{3} \mathrm{~V}_{2}$ & $35.75 \mathrm{a}$ & $522.91 \mathrm{a}$ & $7883.5 \mathrm{a}$ \\
\hline $\mathrm{S}_{4} \mathrm{~V}_{1}$ & $15.50 \mathrm{~h}$ & $102.69 \mathrm{f}$ & $770.16 \mathrm{~h}$ \\
\hline $\mathrm{S}_{4} \mathrm{~V}_{2}$ & $20.00 \mathrm{efg}$ & $147.56 \mathrm{ef}$ & $1286.90 \mathrm{fgh}$ \\
\hline $\mathrm{S}_{5} \mathrm{~V}_{1}$ & $19.00 \mathrm{fg}$ & $152.00 \mathrm{ef}$ & $1596.00 \mathrm{efg}$ \\
\hline $\mathrm{S}_{5} \mathrm{~V}_{2}$ & $23.25 \mathrm{e}$ & $223.84 \mathrm{~d}$ & $2574.20 \mathrm{~d}$ \\
\hline $\mathrm{S}_{6} \mathrm{~V}_{1}$ & $27.75 \mathrm{~cd}$ & 291.62 c & $3441.20 \mathrm{c}$ \\
\hline $\mathrm{S}_{6} \mathrm{~V}_{2}$ & $30.75 \mathrm{bc}$ & $369.00 \mathrm{~b}$ & $4947.60 \mathrm{~b}$ \\
\hline $\begin{array}{l}\text { Level of significance } \\
\qquad(P)\end{array}$ & $<0.001$ & $<0.001$ & $<0.001$ \\
\hline
\end{tabular}

zMeans with different letter ( $\mathrm{s}$ ) is significantly different by Tukey's test at $\mathrm{P} \leq 0.05$. P represents the level of significance of two-way ANOVA. DAT - Days after transplanting. S1: $1 / 2$ strength Rahman and Inden (2012), S2: 3/4 strength Rahman and Inden (2012), S3: Full strength Rahman and Inden (2012), S4: 1/2 strength Hoagland and Arnon No. 2(1940), S5: 3/4 strength Hoagland and 
Arnon No. 2(1940) and S6: Full strength Hoagland and Arnon No. 2 (1940). V1: Local market cherry tomato (red), V2: Irelands cherry tomato (yellow).

Average weight per cluster: Different strengths of nutrient solutions varied significantly in terms of average weight per cluster of cherry tomato (Table 7). The highest average weight per cluster (451.96 g) was recorded from S3, whereas the lowest (125.13 g) was found from S4. This might be because of proper supply of nutrient in the plants. When all the plant nutrients with the growth promoters and the regulators were supplied, the metabolic function of the plants would progress in the right direction and rate, whereas the yield and yield contributing characters increased gradually stated by Rahman and Inden (2012a). In the present study, S3 can supply proper amount in available forms of nutrients to the plants resulting maximum fruit number and uniform shape and size. It has been observed that cluster weight per plant increased gradually with the increasing strength of nutrient solution.

Different cherry tomato varieties revealed significant differences on average weight per cluster (Table 7). The highest average weight per cluster (285.50 g) was recorded from V2, whereas the lowest (204.70 g) was observed from V1. This variation in average weight per cluster might be due to inverse relationship existing between average fruit weight, and number of fruits per cluster. This was conformity with the findings of Prema et al. (2011) and Islam et al. (2012).

Average weight per cluster varied significantly due to the combined effect of different strengths of nutrient solutions and varieties (Table 8). The highest average weight per cluster (522.91 g) was recorded from S3V2 and the lowest (102.69 g) was observed from S1V1.

Average fruit weight per plant: Average fruit weight per plant had significance variation due to different strengths of nutrient solutions (Table 7). The highest average fruit weight per plant (7250.10 g) was found in S3 and the lowest (1028.50 g) in S4. This might be due to S3 produced higher number of flowers per cluster, number of fruits per cluster and number of clusters per plant. Full strength Rhaman and Inden solution might provide all nutrients in a balanced way and a slight acidic condition which helped to grow vegetative growth of plant. Quamruzzaman et al. (2018) reported that adequate supply of nutrient helped get higher yield.

Average fruit weight per plant showed highly significant values between the cherry tomato varieties (Table 7). The highest (3821.00 g) average fruit weight per plant was recorded in V2 and the lowest (2416.00 g) in V1. This might be due to that V2 produced higher number of flowers per cluster, number of fruits per cluster and number of clusters per plant. These results are in agreement with those obtained Prema et al. (2011), Singh et al. (2013). Mehraj et al. (2014) also observed that yield per plant varied significantly among the tomato varieties.

Significant variation was noted on average fruit weight per plant by combination of different strengths of nutrient solution and varieties. The highest (7883.5 g) average fruit weight per plant was recorded from S3V2 and the lowest (770.16 g) were found in S4V1.

In conclusion, full strength Rahman and Inden nutrient solution (S3) showed the maximum performance in respect of growth and yield contributing parameters of hydroponic cherry tomato. In respect of growth and yield parameter, V2 variety of cherry tomato performed better as compared to other variety. Therefore, it can be concluded cherry tomato cv. V2 can be grown in hydroponic system with applying full strength Rhaman and Inden nutrient with higher yield in Bangladesh. 


\section{ACKNOWLEDGEMENTS}

The authors acknowledge the generous and stimulating financial support of Bangladesh Academy of Sciences (BAS) and United States Department of Agriculture (USDA) for the project BAS-USDA-SAU-CR-07. This publication work was carried out as a part of this project and partial fulfilment for the degree of $\mathrm{PhD}$.

\section{REFERENCES}

Adrover, M., Moya, G. and Vadell, J. (2013). Use of hydroponics culture to assess nutrient supply by treated wastewater. J. Env. Man. 127:162-165. Retrieved from https://doi.org/10.1016/j.jenvman.2013.04.044

Aguirre, N. C. and Cabrera, F. A. V. (2012). Evaluating the fruit production and quality of Cherry tomato (Solanum lycopersicum var. cerasiforme). Rev. Fac. Nac. Agron. Medellín [online], 65: 2, pp.6593-6604. Retrieved from Http://www.scielo.org.co/scielo.php?script=sci_arttext\&pid=S030428472012000200004\&lng=en\&nrm=iso>. ISSN 0304-2847

Ahmed, S.U.,Saha, H. K., Rahman, L. and Sharfuddin, A. F. M. (1988). Performance of some advance lines of tomato. Bangladesh Hort. 14(1) : 47-48.

Anonymous, (2009b). Cherry tomato nutritional information ; USDA National Nutritional Database for Standard Reference. Retrieved from Www.loseweight-withus.com/cherrytomato-nutrition. Html

Arnon, D.L., and D.R. Hoagland. (1940). Crop production in artificial culture solutions and in soils with special reference to factors influencing yields and absorption of inorganic nutrients. Soils Science 50:463-483 [Hoagland and $\begin{array}{lllll}\text { Arnon } & \text { No. } & 2 & \text { (1940)]. } & \text { Retrieved }\end{array}$ https://www.cabdirect.org/cabdirect/abstract/19411900537

Arun, J., Amit, V. and Thakur, M. C. (2004). Studied on genetic variability, correlation and path analysis for yield physi cchemical traits in tomato (Lycopersicon esculentum Mill.). Prog. Hort., 36(1): 51-58.

Asao, T. (2012). Hydroponics - A Standard Methodology for Plant Biological Researches. Rijeka, Croatia: In Tech. Retrieved from https://doi.org/10.5772/2215

Asri, F.O., Demirtas, E.I. and Ari, N. (2015). Changes in fruit yield, quality and nutrient concentrations in response to soil humic acid applications in processing tomato. Bulgarian J. Agril. Sci. 21: 585- 591. Retrieved from http://www.agrojournal.org/21/03-17.pdf

Avidan, A. (2000). The use of substrates in Israel. World congress on 'Soilless Culture on Agriculture in the coming millennium.' Maale Hachamisha, Israel. p.17.

Barbosa, G.L., Daiane, F., Gadelha, A. and Kublik, N. (2015). Comparison of land, water, and energy requirements of lettuce grown using hydroponic vs. conventional agricultural methods. Intl. J. Env. Res. and Public Health. 12:6879-6891. Retrieved from https://doi.org/10.3390/ijerph120606879

Da Silva Cuba, R., Do Carmo, J.R., Fonseca Souza, C. and Bastos, R.G. (2015). Potencial de efluente de esgoto doméstico tratado como fonte de água e nutrientes no cultivo hidropônico de alface. Revista Ambiente \& Água. 10(3):574-586. Retrieved from https://doi.org/10.4136/ambi-agua.1575

Deepa, S. and Thakur, M. C. (2008). Evaluation of diallel progenies for yield and its contributing traits in tomato under mid-hill conditions. Indian J. Hort. 65(3): 
$297-301$.

Retrieved

from

https://www.indianjournals.com/ijor.aspx?target=ijor:ijh\&volume=65\&iss ue $=3$ \&article $=011$

Garrison, S.A., Taylor, G.A. and Brinkwater, W.O. (2010). The influence of N nutrition on flowering, fruit set and yield of processing tomatoes. Proc. Amer. Soc. Hort. Sci. 91: 534-543.

Haque, M. S., Islam, M. T. and Rahman, M. (1999). Studies on the presentation of semi-concentrated tomato juice. Bangladesh J. Agril. Sci. 26(1): 37-43.

Hirofumi Ibayash, Y. K., Kaneda, Y., Imahara, J., Oishi, N., Kuroda, M., \& Mineno, H. (2016). A reliable wireless control system for tomato hydroponics. Sensors. 16(5): 644. Retrieved from https://doi.org/10.3390/s16050644

Ilahy, R. (2016). Fractionate analysis of the phytochemical composition and antioxidant activities in advanced breeding lines of high-lycopene tomatoes. Food \& Function. 7(1):574-583. Retrieved from https://doi.org/10.1039/C5F000553A

Islam, M. S., Mohanta, H. C., Ismail, M. R., Rafil, M. Y. and Malek, M. A. (2012). Genetic variability and trait relationship in Cherry tomato (Solanum lycopersicum L. var. (Dunnal) A. Gray). Bangladesh J. Bot. 41(2): 163-167. Retrieved from https://doi.org/10.3329/bjb.v41i2.13443

Kumar, K. (2011). Evaluation of superior Lines of tomato (Lycopersicon esculentum Mill. MS thesis, Dpt. of Horticulture, Institute of Agric. Sci., Banaras Hindu University, Varanasi. P.45.

Lakkireddy, K.K.R., Kasturi, K. and Sambasiva Rao, K.R.S. (2012). Role of Hydroponics and Aeroponics in Soilless Culture in Commercial Food Production. Res. Rev. J. Agric. Sci. Technol. 1, 26-35.

Logendra, L. S. (2009). Greenhouse tomato limited cluster production systems: crop management practices aspect yield. Hort Sci. 36(5):893-896. Retrieved from https://doi.org/10.21273/HORTSCI.36.5.893

Matos, J., Gonçalves, J.S. \& Torres, M.B. (2015). An automatic mechanical system for hydroponics fodder production. The Romanian Review Precision Mechanics, Optics \& Mechatronics. 47:63-71. Retrieved from https://www.researchgate.net/profile/Paulo-Goncalves-

8/publication/286469467_An_automatic_mechanical_system_for_hydropo nics_fodder_production/links/56df458e08ae9b93f79a9277/Anautomatic-mechanical-system-for-hydroponics-fodder-production.pdf

Mehraj, H., Mutahera, S., Roni, M. Z. K., Nahiyan, A. S. M. \& Jamal Uddin, A. F. M. (2014). Performance assessment of twenty tomato cultivar for summer cultivation. J. Sci. Technology and Environment Informatics. 1(1):45-53.

Mohanraj, I. K. N. (2016). Field monitoring and automation using IOT in Agriculture Domain. Procedia Computer Science, 93, 931-939. (IEEE 6th International Conference on Advances in Computing \& Communications). Retrieved from http://dx.doi.org/10.1016/j.procs.2016.07.275

Mondal, M.M.A., Imam, M.H. and Razzaque, A.H.M. (2011). Effect of sources of seed on growth and yield of tomato genotypes. Intl. J. Expt. Retrieved from http://ggfjournals.com/assets/uploads/MIN-170_Tomato_(Mondol)_1216_Back_from_Author_(need_some_talk_with_author_).pdf

Nandapuri, K.S., Kurwar, J.C. and Roshanlal, R. (1973). Variability of path analysis discriminant function, selection in tomato. Haryana J. Hort Sci. 6(1 \& 2): 73. 
Nasir, M. U., Hussain, S. and Jabbar, S. (2015). Tomato processing, lycopene and health benefits: a review. Sci. Letter. 3(1):1-5.

Parvej, M. R., Khan, M. A. H. and Awal, M. A. (2010). Phenological development and production potentials of tomato under polyhouse climate. J. Agril. Sci. 5(1): 19-31. Retrieved from https://doi.org/10.4038/jas.v5i1.2329

Perveen, R. (2015). Tomato (Solanum Lycopersicum) carotenoids and lycopenes chemistry: metabolism, absorption, nutrition, and allied health claims: a comprehensive review. Critical Reviews in Food Science and Nutrition. 55(7):919-929. Retrieved from https://doi.org/10.1080/10408398.2012.657809

Prema, G., Indiresh, K. M. and Santhosha, H. M. (2011). Evaluation of cherry tomato (Solanum lycopersicum var. Cerasiforme) genotypes for growth, yield and quality traits. Asian J. Horticulture. 6(1): 181-184.

Quamruzzaman, M., Rahman, M.J. \& Sarkar, M.D. (2017). Leaf gas exchange, physiological growth, yield and biochemical properties of groundnut as influenced by boron in soilless culture J. Plant Interact. 12(1):488-492. Retrieved from https://doi.org/10.1080/17429145.2017.1397206

Quamruzzaman, M., Rahman, M.J., Sarkar, M.D., Uddain, J. \& Subramaniam, S. (2018). Leaf gas exchange, reproductive development, physiological and nutritional changes of peanut as influenced by boron. J. Plant Interact. 13(1):306-314. Retrieved from https://doi.org/10.1080/17429145.2018.1475021

Rahman, M., Quamruzzaman, Md., Uddain, J., Sarkar, M., Islam, M., Zakia, M., \& Subramaniam, S. (2018). Photosynthetic Response and Antioxidant Content of Hydroponic Bitter Gourd as Influenced by Organic Substrates and Nutrient Solution, HortScience horts, 53(9), 1314-1318. Retrieved Apr 8, 2021, Retrieved from https://journals.ashs.org/hortsci/view/journals/hortsci/53/9/articlep1314.xml

Rahman, M.J. \& Inden, H. (2012a). Antioxidants contents and quality of fruits as affected by nigari, an effluent of salt industries, and fruit age of sweet pepper (Capsicum annuum L.) J. Agril. Sci, 4: 105-114. Retrieved from https://doi.org/10.5539/jas.v4n10p105

Rahman, M.J., Inden, H. \& Hossain, M.M. (2012b). Capsaicin content in sweet pepper (Capsicum annuum L.) under temperature stress. Acta Hort. 936:195-201. Retrieved from https://doi.org/10.17660/ActaHortic.2012.936.23

Rana, S., Bag, S.K., Golder, D., Mukherjee Roy, S., Pradhan, C. and Jana, B.B. (2011). Reclamation of municipal domestic wastewater by aquaponics of tomato plants. Ecological Engineering. 37:981-988. Retrieved from https://doi.org/10.1016/j.ecoleng.2011.01.009

Rashid, MM. (1983). Sabjeer Chash, 1st Edn., Begum Shahla Rashid Publishers, Joydebpur , Gajipur, 86-87.

Resh, H.M. (2012). Hydroponic food production: a definitive guidebook for the advanced home gardener and the commercial hydroponic grower. CRC Press.

Savvas, D. (2003). Hydroponics: A modern technology supporting the application of integrated crop management in greenhouse. J. Food Agric. Environ. 1: 80-86.

Singh, V. A. K., Bhatia, D., Duhan, D., Majoka, M. and Amit Singh. (2013). Performance of different tomato hybrids under greenhouse conditions. Crop Res. Hisar. 46(1/3): 188-191. Retrieved from https://web.a.ebscohost.com/abstract?direct=true\&profile=ehost\&scope= 
site\&auth type $=$ crawler\&jrnl $=09704884 \& A N=96003104 \& \mathrm{~h}=\mathrm{t} 0 \% 2 \mathrm{bI}$ I MSUg bfk\%2fxzNHcE60ZeR1CCUGDsWwsgQzlkob4\%2bEm6EjuU8KqwNQN9VU eL59h\%2f1cry4AlqjemZy8q3ELIA\%3d\%3d\&crl=c\&resultNs=AdminWebA uth\&resultLocal=ErrCrlNotAuth\&crlhashurl=login.aspx\%3fdirect\%3dtrue \%26profile\%3dehost\%26scope\%3dsite\%26authtype\%3dcrawler\%26jrnl \%3d09704884\%26AN\%3d96003104

Spray, A., \& Spray, H. (2019). Hydroponics farming provides fresh produce yearround. Retrieved from Illinois Farm Families: Retrieved from https://www.watchusgrow.org/2019/03/18/hydroponicfarmingprovides-fresh-produce-year-round/

Thangam, M. and Thamburaj, S. (2008). Comparative performance of tomato varieties and hybrids under shade and open conditions. Indian J. Horticulture. 65(4): 429-433. Retrieved from https://www.indianjournals.com/ijor.aspx?target=ijor:ijh\&volume=65\&iss ue $=4 \&$ article $=012$

Vinha, A. F. (2014). Organic versus conventional tomatoes: influence on physicochemical parameters, bioactive compounds and sensorial attributes. Food Chemical Toxicology. 67(1):139-144. Retrieved from https://doi.org/10.1016/j.fct.2014.02.018

Viviano, F. (2017). This Tiny Country Feeds the World. Retrieved from National Geographic:

Retrieved

from

http://www.nationalgeographic.com/magazine/2017/09/hollandagriculture-sustainablefarming/ 